Процик I. В. кандидат філологічних наук, ст. викладач Запорізький начіональний університет

\title{
ВПЛИВ ФІЛОСОФІЇ СХОДУ І ПРАЦЬ В. СОЛОВЙОВА НА ТВОРЧІСТЬ М. ОРЕСТА
}

Стаття присвячена проблемі впливу філософії Сходу та прачь В.Соловйова в поезії М.Ореста. Ідеї про зв'язок між природою $і$ життям людини, перемогу добра в боротьбі добра зі злом, відповідальності людини, єдності людства, безсмертя душі, переродження виявилися при аналізі поезії. Автор використав образи природи, зокрема дерев, весни як пори відродження, міста як осердя добра $і$ зла. Особливу увагу М.Орест приділив питанню морального вдосконалення людства.

Ключевые слова: мораль, природа, людина. 
Статья посвящена проблеме влияния философии Востока и трудов В.Соловьёва в поэзии М.Ореста. Идеи о связи между природой и жизнью челове$\kappa a$, победе добра в борьбе добра со злом, ответственности человека, единстве человечества, бессмертии души, перерождения были выявлены при анализе поэзии. Автор использовал образы природы, в частности деревьев, весны как поры возрождения, города как средоточия добра и зла. Особенное внимание М.Орест уделил вопросу морального усовершенствования человечества.

Ключові слова: мораль, природа, человек.

The article devoted to the problem of influence of the philosophy of East and works of V.Solovjov in the poetry of M.Orest. Ideas about connection between the nature and people's life, the victory of good in the fight between good and evil, responsibility of human, unity of humanity, undying of soul, transformation shows in analysis of poetry. The author used images of nature, in particular trees, spring as the season of rebirth, city as the plase of good and evil. The special attention M.Orest devoted to the question of moral perfection of humanity.

Kyewords: morals, nature, person.

Творча спадщина М.Ореста багатогранна і неординарна, як і творчість будь-якого митця. П'ять поетичних збірок, переклади творів класиків світової літератури - це лише частка 3-поміж тих матеріалів, які відомі і доступні широкому загалу. Ореол таємничості навколо імені поета досі існує. Дуже багато сторінок його біографії так і лишаються білими плямами, а ті відомості, які $\epsilon$, здебільшого стосуються часу перебування в еміграції. Звичайно, така ситуація позначається на дослідженні творчості М.Ореста. Предметом уваги літературознавців стають переважно питання стилю, превалюючих образів, їхньої генези та семантики [Бросаліна 2003, Державин 1994, Заславський 1996, Ільницький 1994]. С розвідки, присвячені невідомим сторінкам з епістолярної спадщини М.Ореста, свідчення сучасників поета, тих людей, хто був з ним особисто знайомий [Ізарський 1964]. Питання зовнішніх впливів у творчості поета здається дуже важливою проблемою, яка дасть змогу більш глибоко усвідомити значення вже не раз досліджуваних та інтерпретованих образів (наприклад, лісу, дерев) у поезії письменника, а й зрозуміти причини, через які автор використав 
саме ці певні образи, той спосіб, у який ці образи було введено до змісту творів. Про впливи у поезії М.Ореста досі було сказано лише побіжно, проте думка щодо унікальності його стилю і світоглядних установок розвинена більш детально, що неминуче призводить до проектування результатів пошуку зв'язків між внутрішнім світом та його відбиттям у творчості автора у площину витоків, закономірностей виникнення цих зв'язків. Віднайшовши вияв ідеї „східного пантеїзму” в поезії „До вас, ліси, в побожному мовчанні..." при окресленні чотирьох основних тем у творчості М.Ореста, Яр Славутич віднайшов підтвердження цій тезі в поемі „Відхід лісів” [Славутич 2006: 382-383]. С.Павличко висловила думку про те, що М.Орест споріднений із французькими та німецькими символістами, і головний іï аргумент такий: „Свропейський символізм рубежу віків наснажувався ідеями Артура Шопенгауера про подвійність світу і духовне обгрунтування реальностей; Орест сприймав нову ідеалістичну філософію передовсім через праці Володимира Соловйова. (Про Орестове захоплення Соловйовим згадує Олег Зуєвський)" [Павличко 1995: 8]. Метою цієї статті є спроба виявити головні ознаки впливу філософії Сходу та праць В.Соловйова у поезії М.Ореста.

Кожен творчий здобуток неминуче має відбиток свого автора, його світогляду, способу його мислення. Тема природи в поезіі М.Ореста посідає чільне місце й набуває глибинного звучання завдяки осмисленню автором іiї життєдайної вічної сили й мудрості. Вона є втіленням найвищої духовності, яка, на думку М.Ореста, має бути відроджена й у світі людей. Глобальність і глибина поезії М.Ореста досягається насамперед завдяки тому, що він порушив проблеми духовності, єдності людини й природи та людства. Для ліричного героя М.Ореста природа мудріша за людину, а дерева носії знання, яке можна черпати, лише дослухаючись до їхніх таємничих голосів. Ліриці М.Ореста властиве самозаглиблення, самоаналіз. Життєве кредо М.Ореста відповідає поглядам В.Соловйова, філософією якого захоплювався поет. У праці „Сенс любові” ро- 
сійський філософ стверджував, що природа є світовою волею, несвідомим або надсвідомим світовим духом. Саме таке трактування природи як ірраціонального визначника буття, який скеровує людину й людство загалом, наявне в поезії М.Ореста. Шлях споріднення $з$ природою, за М.Орестом, допоможе людству звернутися до добра, збагнути своє призначення, реалізувати духовне покликання. За К.-Г.Юнгом, «...до того часу, поки ми заглиблені в природу, ми несвідомі, і живемо під захистом інстинкту, який не відає проблем» [Юнг 1997: 14]. Сучасна для нього дійсність у поезії „Прийдешнє - пуща, в пітьмі вся, німа...” постає в образі темної, німої пущі, де стежками мають бути слова, яких немає. Світ природи приховує в собі світле начало, що відкриває погляд на людське існування, яке є вічним, оскільки продовжується в нових формах, якісно перетворюючись. Людина не усвідомлюється як приречена зі своїми моральними вадами в поезії М.Ореста „Не видно берега у сивій млі...”, а як така, яка може стати на правильний шлях у житті. Усвідомлення власної недосконалості повинно бути постійним: «I я боюсь краӥни запашної / Не отемнити власною труною» [Орест 1995: 62].

Ці погляди є наслідком захоплення М.Ореста Східною філософією. Віровчення індуїзму й буддизму різняться, та суть їх полягає в перевтіленні, переселенні душі людини після смерті в іншу людину, тварину, рослину. Людська душа - це Атман, „Я” людини, яке весь час прагне з'єднатися з Абсолютом-Брахмою (світовою душею), яка є в самій людині, є частиною Абсолюту. Сенс життя полягає в єднанні Атмана 3 Абсолютом [Лубський 2003: 157]. Адже допоки душа Атман не з'єднається з Абсолютом, вона за суттю своєю ще не є світлою. У буддизмі перевтілення душі відбувається за законами карми (ідеї відплати). Бог народжує 3 себе світ і вбирає його в себе. Людина при цьому - ніщо. У буддизмі душа - психологічна єдність, яка є основою людської особистості й пізнає світ і людину передусім через саму себе. Шлях до єднання - в добрих справах, любові, знанні. Наявність двох типів 
лісів, дерев у поезії М.Ореста - вияв його релігійних зацікавлень і міркувань.

У поезії „Минуле зноситься березою гінкою...” є думка про те, що земне буття дає мало благ: «Мутний його бурун без ияілі й правди рине / I гідно ми живем лише скупі години» [Орест 1995: 64]. Метафора «бурун буття» вказує на те, що життя схоже на навальну пінисту хвилю, вода в якій забруднена. Цю каламуть М.Орест тлумачив насамперед як моральну недосконалість і душевну вбогість. Він прагне злитися в гармонії з душею лісу, називаючи себе блудним сином. Передбачаючи власне безсмертя, ліричний герой уявляє своє подальше існування як людське, але разом із тим це буде якісно нове існування в природі й через природу, яке схоже на людське: «Хай буду в кронах думати високих / I говорити в лепеті листків, / В квітках радіти і в могутніх соках / Дрімати тихо до кіния віків!» [Орест 1995: 26].

Ідеї безсмертя і відродження безпосередньо пов'язані з весною, яка постає в образі цариці, ,злотобарвний трон” якої сяє серед лісу на галявині, що співвідноситься 3 народними уявленнями про цю пору року. «Кроткі лані» [Орест 1995: 24], які обступили трон весни, свідчать про обраність цієї пори року, бо лані, лосі та олені вважаються небесними істотами, що відбилося в культі цих тварин як жертовних [Рибаков 1981: 54-74]. Крім того, олень є символом довголіття [ЕС 2000: 50]. «Безсмертя посли» [Орест 1995: 40] - так метафорично названі два білі олені, які приходять по ліричного героя («У ложах камінних прозорчасті струмені...», епіграф - слова $з$ твору В.Соловйова). Краєвиди навесні уподібнені до неба, і душа людини теж підноситься вгору найвищим, що має: любов'ю, осяянням і вірою. Саме навесні посилюється зв'язок між природою і людиною, живими й померлими.

Ліричний герой М.Ореста, вірячи в безсмертя душі, вважає людей на землі гостями, тимчасовими мешканцями, які одвічно блукають у далеких дорогах, мандрують у пошуках власного земного щастя, що є виявом впливу філософії Сходу. Пора весни да- 
рує надію на воскресіння навіть тому, що «видатись могло невоскресимим» [Орест 1995: 70]. Обриси святині, яку прагнуть знайти пілігрими, шукачі нематеріальних скарбів, уже відбилися в їх сумних очах, що є наслідком втрати надії та віри в краще. Метафора «грім ликуючих дзвіницьъ [Орест 1995: 70] увиразнює мотив торжества добра на землі. Для М.Ореста на перший план виходять хвороби душі та проблеми духовності. Глобальність мислення виявляється в тому, що ліричний герой М.Ореста спостерігає духовний занепад людства. Там, де $є$ люди, існує зло на противагу добру. Ліричний герой доходить висновку, що поза людьми не може існувати така жорстокість, бо причина зла в самих людях, у суперечливій людській природі. Людині дано багато: і розум, i здатність переживати певні почуття й емоції, спілкуватися за допомогою мови, але разом із тим на неї покладено моральну відповідальність за свої вчинки через право обирати: «Ми є творичі своєї долі, нам / На вільний вибір дано, щзо пустити / 3 душі діяння, чи зле, чи добре...» [Орест 1995: 79]. В «Афоризмах» люди постають як «життя будівничі», які обирають поміж добром і злом, що дуже відповідально й не терпить поспіху: «Стій, роздивися: котру в руки цеглину береш?» [Орест 1995: 114]. Для того, щоб подолати зло у світі, людині треба побороти це зло у своїй душі, що споріднює ліричного героя М.Ореста з Г.Сковородою. Ідея про те, що «3 зерна бажання розбуяє радість!» [Орест 1995: 153] в поезії «Уговір» віддзеркалює філософське бачення людини-сіяча на власній життєвій ниві і виявляє захоплення М.Ореста буддизмом, за вченням якого шлях до нірвани пролягає через вісім сходинок, серед яких зокрема $є$ правильна думка, дія та бажання, що взаємопов'язані між собою.

Світ в інтерпретації М.Ореста постає в образі терезів, чаші яких постійно коливаються в напрузі: «Лежать на чашах існування наші. / Світ, знаний нам, - гігантські терези» [Орест 1995: 151]. По той бік несталих коливань терезів людям, які страждали за життя, призначене щастя, виважене, усталене, яке допомагає 
віднайти внутрішню гармонію, на думку ліричного героя. Можливо, ще не пізно, і є шанс змінити життя на краще. Ця ідея суголосна процесу відродження, який відбувається з пробудженням природи навесні. Ліричного героя М.Ореста більше хвилює не його особиста доля, а те, що людство ще не приречене. Великоднє свято дає надію на порятунок від зла. «Велике, Мирне, Любляче, Безплотне» [Орест 1995: 83] для ліричного героя не є маною чи міфом. Світ, обтяжений злом, не забуває цих одвічних істин, а значить, надає їм буття. Справжня «Суть» [Орест 1995: 83] людини, на думку ліричного героя, закута в лід, прихована за маскою душевної черствості. Людина ж, за переконанням М.Ореста, створена для того, щоб бути носієм добра. Життя - це страждання, зумовлене, за філософією буддизму, якою захоплювався М.Орест, бажаннями людини. А позбутися їх можна за допомогою восьмисходинкового шляху, тоді духовний рівень людини стане значно вищим: «Ми вступимо у наше Воскресіння / I в гонг ударимо алмазних брам» [Орест 1995: 84]. Такий евфемічний вислів свідчить про віру поета в моральне спасіння людини.

Ліс у поезії М.Ореста - божественний носій мудрості, а дім лише тимчасове місце перебування людини. Серце тужить за лісами. Постає питання про те, коли ж ліричний герой буде не лише гостем у лісі, а зіллється 3 ним. Саме тоді прийде відчуття, що тління немає, а душа, лишивши світ суєти, «В собі відчує ніжне колосіння - / Знак невмирущзого свого буття!» [Орест 1995: 48]. Називаючи ліс «величавим» [Орест 1995: 48], «гоїтелем душі» [Орест 1995: 48], ліричний герой усвідомлює конечність свого буття на відміну від лісу, який причетний до божественного світу (на це вказує епітет «нетлінні риси»), де смерті не існує: «Як херувимів рать, старі стоять дуби...» [Орест 1995: 49]. Ліричний герой стає учасником ініціації, мета якої - внутрішнє вдосконалення, моральне й духовне переродження людини. Природа, зокрема ліс, на думку М.Ореста, допомагає людині спізнати істину. Саме до дубів як до «праотців» приходить ліричний герой із бажанням спізнати минуле, та вони 
віщують майбутнє, лунає «лепет горньої свободи» [Орест 1995: 120], що свідчить про захоплення М.Ореста пантеїстичними ідеями. Людина йде за знаннями до природи восени, в час, коли відбувається перегляд минулого. М.Орест проводить паралель між осіннім лісом-,Подвижником” [Орест 1995: 122], який зрікається світу, та Буддою. Людина має прийти до світу природи за мудрістю як до божества, як Ашока - онук першого царя династії Маур'їв, який, прийнявши буддизм, згуртував народи, що заселяли територію Індії у III ст. до н. е. Проте правитель не заперечував існування джайнізму, брахманізму, адживістських общин [ICC 1989: 463-467]. Мудрий Ашока втілив у життя мудрість з Упанішад: існує багато думок, і всі вони мають право на існування, тому що суще - єдине, тільки назване різними іменами. Він приходить до Будди освятити скіпетр як символ влади і вінець, який у цьому контексті можна трактувати не тільки як символ перемоги, а й ініціації, оскільки цар як людина світська зумів якоюсь мірою долучитися до аскези: «...I тішить дух двоодність іпостасі: / Цар лагідний $і$ благосний чернещь» [Орест 1995: 123].

Поезія «Перед пралісом» підтверджує думку про єдність буття. Людина, на думку М.Ореста, має дослухатися до поклику «Одності» [Орест 1995: 156], щоб вступити до їі кола - символу нескінченності, що означає стати причетним до потойбічного світу, отримати нове, невідоме досі знання. У ніч на Купала той, хто знаходив квітку папороті, швидко окреслював коло навкруг цього місця, інакше злі сили могли завдати шкоди. За легендою, квітка папороті приносить щастя і дає змогу розуміти мову тварин і рослин. Коло, до якого хоче вступити ліричний герой, символізує найвищу мудрість, завдяки якій людина стає адептом. Дерева «незнаного Судді сини» [Орест 1995: 161], свідки людських гріхів. Із вуст ліричного героя звучить риторичне питання, яке підтверджує думку про вищість природи над людиною: «I, як настане Суд, чи слово змовлять, / Щоб захистити нас, вони - дерева?» [Орест 1995: 162]. 
Світ - ворожий і підступний, поступово знищує душу людини, на думку поета і його ліричного героя. Сдине місце, де він не владний зі своїми законами, - це ліс, який є «зеленим храмом2 [Орест 1995: 67]. Ліричний герой передбачає підступність світу, який може завадити наблизитися до лісу, що викликає в нього почуття небезпеки, страху або відчаю, виникає бажання «повернутися з буття на свободі назад, у те зв'язане, рослинне, з якого були відпущені в самотність» [Шпенглер 1998: 6]. Ліричний герой втече від світу, перетворившись на дуб, що є виявом архетипу Переродження, який є базовим у буддизмі. У поезії «До вас, ліси, в побожному мовчанні...» це синтез процесу переселення душі (серце ліричного героя є часткою душі) із процесом трансформації (людина перетворюється на дерево): «Я стану листям, міцно окує / Кора, як панциир, - голову і груди, / I в дубі серие скриється моє» [Орест 1995: 67]. Проектуючи власне безсмертя, ліричний герой також ототожнює себе 3 липою: «Як солодко липою думати себе...» [Орест 1995: 46]. Контрастом до світу природи виступає світ людської цивілізації.

Місто часів Великої Вітчизняної війни змальоване М.Орестом за допомогою прийому контрасту: пишнота міст, колись піднесена до неба банями церков, у час війни «Додолу звалищзами опадала / Без форми, імені і без обличчя» [Орест 1995: 109], «тьмяні майдани» були «оточені скелетами домів». «Країни світич» [Орест 1995: 79], місто, перебуває під впливом „чорної згуби". У цей лиховісний час навіть дерева покидають цю землю. Ліричний герой шукає допомоги у дерев, але розуміє, що він $є$ людиною, на якій «Тяжіла також частка вин найтяжчих, / Що спричинили сколих світо твору» [Орест 1995: 112]. За масштабні катастрофи, війни й біди відповідає не кожна людина окремо, а все людство, що є відбитком народних уявлень про те, що нащадки відповідають за гріхи своїх предків, а також думка про єдність людства в його моральній і духовній недосконалості, що свідчить про вплив В. Соловйова на поетову творчість. Людина дедалі бі- 
льше відмежовує себе від світу, від оточуючих, самоутверджуючись, що породжує егоїзм. Таке протиставлення себе іншим людям $\epsilon$, на думку В.Соловйова, «...корінним злом нашої природи» [Соловйов 2004: 178]. І далі: «Якщо раніме людина мала у своїи свідомості пряме вираження всезагального органічного зв'язку того, щзо існує, і ичим зв'язком (ідеєю всеєдності) визначався увесь зміст іï свідомості, то тепер, переставши мати цей зв'язок у собі, людина губить в ньому начало свого внутрішнього світу, що організовує, - світ свідомості перетворюється на хаос» [Соловйов 2004: 207]. Ідея про єдність людства та одне джерело життя стає превалюючою: «Ми, люди, живемо серед родини...» [Орест 1995: 158]. I вагомим аргументом на користь цієї думки для ліричного героя $\epsilon$ гармонія в природі.

Поема «Видіння» ілюструє погляди ліричного героя на світ, за якими різко протиставлено природу й реальність, що позначена втратою моралі й пануванням зла. Роки зробили «корінь єства» [Орест 1995: 76] ліричного героя неміцним, втомленим боротьбою зі злом. Ця втома заполонює душу, й людина знову змушена по смерті втілитися в новій істоті, щоб спокутувати власну недосконалість, яка є виявом закону карми, що свідчить про захоплення М.Ореста філософією буддизму, органічно поєднаною з християнськими догмами. Біда заглушує голос душі, який оспівує «рясноту овочів земних» [Орест 1995: 78], любов і «благоденство», що є відбитком поглядів на біблійні плоди духу. Світ реальності більше злий, аніж добрий, на думку ліричного героя, який став свідком його найнижчого падіння, його душа не в силі протистояти злу: «Душе моя, скиталице боляща, / 3 чим прийдеш ти у потойбічний світ?» [Орест 1995: 78]. Концептуальність цього змісту в тому, що для М.Ореста фізична смерть не уявлялася як незворотна. Ідея про вічне життя $\epsilon$ у християнстві, а в буддизмі актуалізована ідея перевтілення людини по смерті на іншу істоту, що також ілюструє невмирущість.

У дистихові з циклу «Східна мудрість» М.Орест афористично змалював єдність духовного й тілесного в людині за допомогою 
образу міста, яке він порівняв із тілом, тобто матеріальним, поєднаним із духовним: «...де добро $і$ де зло повеніє; / Ти в нім - султан, а твоя совість - великий везір» [Орест 1995: 115]. Людина відповідальна за свої вчинки й вільна чинити так, як забажає. Лише від неї залежить, чи діятиме вона з позиції зла або добра. Така думка в поезії М.Ореста суголосна міркуванням В.Соловйова: «Сучасна свідомість визнає за людською особистістю божественні права, але не дає їи ні божественних сил, ні божественного змісту, оскільки сучасна людина $і$ в житті, $і$ в знанні допускає тільки обмежену умовну дійсність, дійсність одиничних фактів $i$ явищ, $і$ з иієї точки зору сама людина є лище одним із цих одиничних фактів» [Соловйов 2004: 27].

Вживаючи священний склад індуїстів $O M$, ліричний герой закликає вищу силу, яка має освятити сказані слова: «С тільки дух, благе не гине, ом!» [Орест 1995: 90]. Хоча традиційно цей склад ставиться на початку фрази і є символом трьох етапів космічного циклу: створення, збереження, розчинення. У буддизмі це також символ космічної тріади богів - Шиви-руйнатора, Вишну-творця та Брахми - верховного бога [Шейніна 2003: 258]. Отже, ліричний герой прагне закликати вищу силу для утвердження добра, допомоги в самовдосконаленні, самопізнанні. «Боги, знаходячи в изьому складі притулок, стають безсмертними, і людина, яка вимовляє цей склад, стає теж безсмертною подібно до богів» [ДФ 1972: 87].

Утвердження добра, прагнення морального вдосконалення, заклики до єдності людства у відродженні духовних цінностей такі провідні ідеї поезії „слуги високостей”, позначеної впливом філософії Сходу та праць В.Соловйова.

\section{БІБЛІОГРАФІЯ}

Бросаліна 2203 - Бросаліна О. Художньо-естетичні засади неокласицизму і творчість Михайла Ореста та Ігоря Качуровського: автореф. дис. на здобуття наук. ступеня канд. філол. наук : спец. 10.01.01. „Українська література” / О.Бросаліна. К. : Київський національний університет ім. Т. Шевченка, 2003. -18 с. Державин 1994 - Державин В. Поезія Михайла Ореста і неоклясицизм // Українське слово : хрестоматія української літератури та літературної критики XX ст. - 
[у 3 книгах]. / В.Державин - [упор. С.Федоренко, В.Яременко]. - [наук. ред. А.Погрібний]. - Кн. 2. - К. : Рось, 1994. - С. 347-365.

ДФ 1972 - Древнеиндийская философия. Начальный период ; [подгот. текстов, вступит. ст. и коммент. В.В.Бродова]. - [2-е изд.]. - М. : Мысль, 1972. - 271 с. Заславський 1996 - Заславський І. „Мислі й чуття небуденні...” (Поезія Михайла Ореста) / І.Заславський // Слово і час. - 1996. - № 11-12. - С. 1 -18.

Ізарський 1994 - Ізарський О. Михайло Орест у листах / О.Ізарський // Сучасність. - 1964. - № 3 (39). - С. 49 - 61; 1964. - № 4 (40). - С. 70-81.

Ільницький 1994 - Ільницький М. Замкнене в магії слова / М.Ільницький // Дзвін. - 1994. - № 4. - С. 21-22.

ICC 1989 - История Древнего мира : в 3 кн. / [отв. ред. И.С.Свенцицкая] / [под. ред. И.М.Дьяконова, В.Д.Нероновой, И.С.Свенцицкой] ; [изд. 3, испр. и доп.]. Кн. 2. - М : Наука, 1989. - 572 с.

Костецький 2007 - Костецький І. Анатомія піднебесного / І.Костецький // Кур'єр Кривбасу. - Травень - червень 2007. - № 5 - 6 (210 - 211). - С. 297-303. Лубський 2003 - Лубський В. Релігієзнавство: [підручник] / В.І.Лубський, В. І.Теремко, М.В.Лубська. - К. : Академвидав, 2003. - 432 с.

Рибаков 1981 - Рыбаков Б. А. Язычество древних славян / Б.А.Рыбаков. - М. : Наука, 1981. -608 с.

Орест 1995 - Орест М. Держава слова : вірші та переклади / М.Орест. - К. : Основи, 1995. -526 с.

Славутич 2006 - Славутич Яр. Мислитель у поезії : Михайло Орест / Славутич Яр // Дослідження та статті.Розстряляна муза. Меч і перо. Українська література на Заході. - Едмонтон : Славута, 2006. - С. 379-389.

Соловйов 2004 - Соловьев В. С. Чтения о Богочеловечестве / В.Соловьев. - М. : ACT, 2004. $-251 \mathrm{c}$.

Шейніна 2003 - Шейнина Е. Я. Энциклопедия символов / Е.Я.Шейнина. - М. : АСТ ; Харьков : Торсинг, 2003.- 591с.

Шпенглер 1998 - Шпенглер О. Возникновение и ландшафт / О.Шпенглер // Закат Европы : [очерки морфологии мировой истории. 2. Всемирноисторические перспективы] / [пер. с нем. и прим. И.И.Маханькова]. - М. : Мысль, 1998. - С. 5-87.

ЕС 2000 - Эмблемы и символы / [вст. ст. и коммент. А.Е.Маховой]. - [2-е испр. и доп. изд. с оригин. гравюрами 1811 г.]. - М. : Интрада, 2000. - 368 с.

Юнг 1997 - Юнг К. Г. Сознание и бессознательное : Сб. ; [вст. ст., пер. с англ. и науч. ред. А.А.Алексеева]. - СПб : Университетская книга, 1997. - 544 с.

Стаття надійшла 20 жовтня 2013 р. 